\title{
Another one that extends the toe: the Austregésilo-Esposel sign
}

\author{
Uno más que extiende el primer ortejo: el signo de Austregésilo-Esposel
}

Sergio Andrés CASTILLO-TORRES ${ }^{1}$, Fernanda FLORES-ALFARO' ${ }^{1}$, Fernando GÓNGORA-RIVERA ${ }^{1}$

Dear Editor,

With great interest we read the article by Novis and colleagues recently published in Arquivos de Neuro-Psiquiatria ${ }^{1}$. Where they present the life and work of Professor Faustino Esposel, considered the father of Brazilian neurology, who along with Antõnio Austregésilo, described a substitute sign for Babinski's phenomenon eliciting of the extensor plantar response upon squeezing of the thigh: "Le phénomene de Babinski, provoqué par l'excitation de la cuisse", now known as the Austregésilo-Esposel sign². Upon a search of the literature, we were unable to find recent visual documentation of the sign. Therefore, to illustrate the excellent article by Novis and colleagues, we considered it appropriate to present the case of a patient with stroke in whom the Austregésilo-Esposel sign was present, along with the Babinski, Chaddock, and Oppenheim signs.

An 89-year-old female with a long-standing history of untreated hypertension, presents to the emergency department 7 hours after sudden-onset of mutism and right hemiparesis. Neurological examination reveals global aphasia, right dense hemiplegia (0/5 in Modified Research Council scale), with hyperactive deep tendon reflexes and abnormal plantar responses (Figure 1), with toe extension on squeezing of the thigh (Figure 2): the Austregésilo-Esposel sign. A non-contrast enhanced computed tomography of the brain revealed a large left-hemispheric stroke (Figure 3). Etiological work up for the

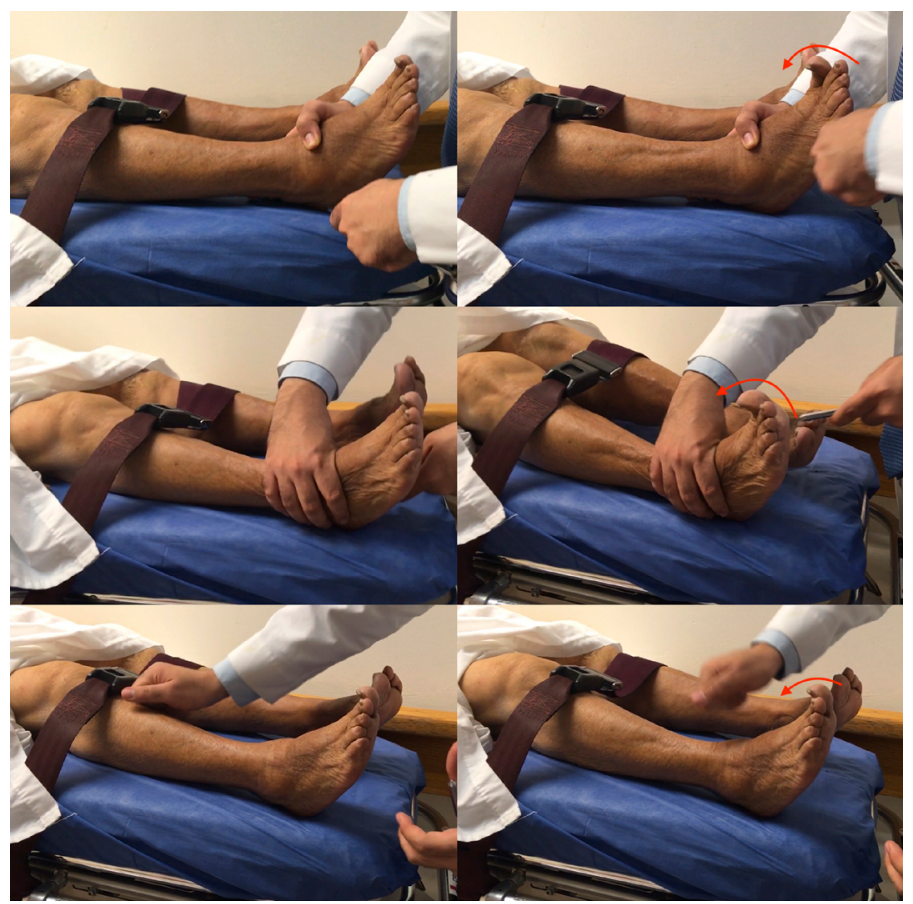

Figure 1. Signs eliciting extensor plantar response. Toe extension on stroking the sole of the foot (Babinski, 1), the lateral aspect of the foot (Chaddock, 2) and downward stroking of the tibia (Oppenheim, 3).

'Universidad Autónoma de Nuevo León, Hospital Universitario “Dr. José Eleuterio González”, Servicio de Neurología, Monterrey, Nuevo León, México. SACT (D) https://orcid.org/0000-0002-4727-2535; FFA (D) https://orcid.org/0000-0002-1570-1681; FGR (D) https://orcid.org/0000-0003-1224-3942 Correspondence: Fernando Góngora-Rivera; Email:fernando.gongora@hotmail.com. Conflict of interest: There is no conflict of interest to declare.

Authors' contributions: SACT, FFA, FGR: contributed to conception and design of the manuscript, acquisition, and interpretation of data; SACT, FFA: drafted the initial manuscript; FGR: performed a critical review of the manuscript, with edition for important intellectual content. All authors approved of the final version. Received on August 02, 2021; Accepted on August 06, 2021. 


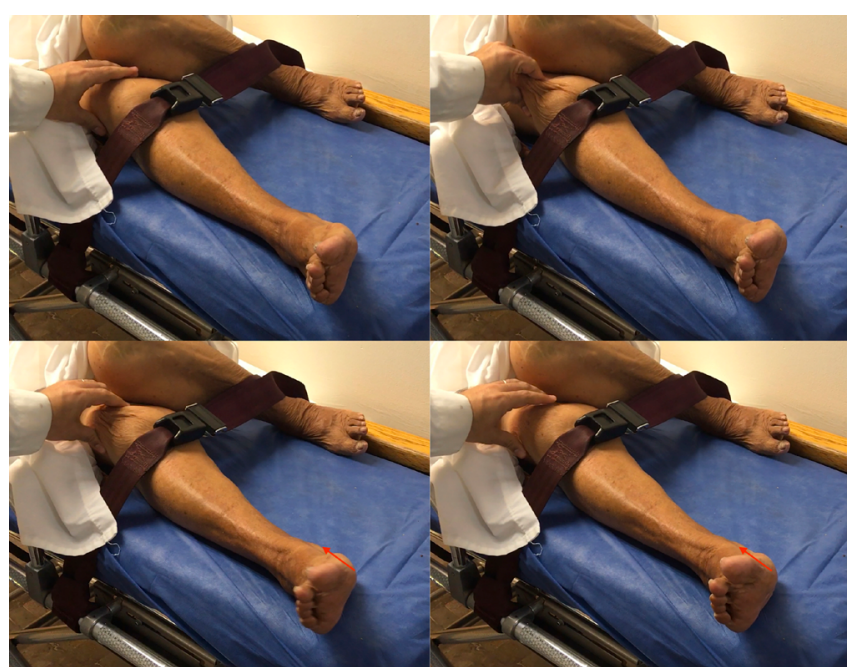

Figure 2. Austregésilo-Esposel sign. Toe extension on squeezing of the anterior aspect of the thigh.

cause of stroke ruled out cardiac embolism sources, large-artery, and small-vessel disease, and was thus classified as an embolic stroke of unknown source (ESUS) ${ }^{3}$.

With over 30 surrogate or substitute signs for the original Babinski sign ${ }^{4}$, it has become a common rite of passage in some centers to test trainees on how many signs they can remember. Despite their widespread use as markers of corticospinal disease, their diagnostic yield remains controversial; and their sensitivity for detecting pyramidal tract dysfunction and inter observer agreement remains low ${ }^{5}$. Thus, regardless of the eponym remembered when eliciting the plantar response,

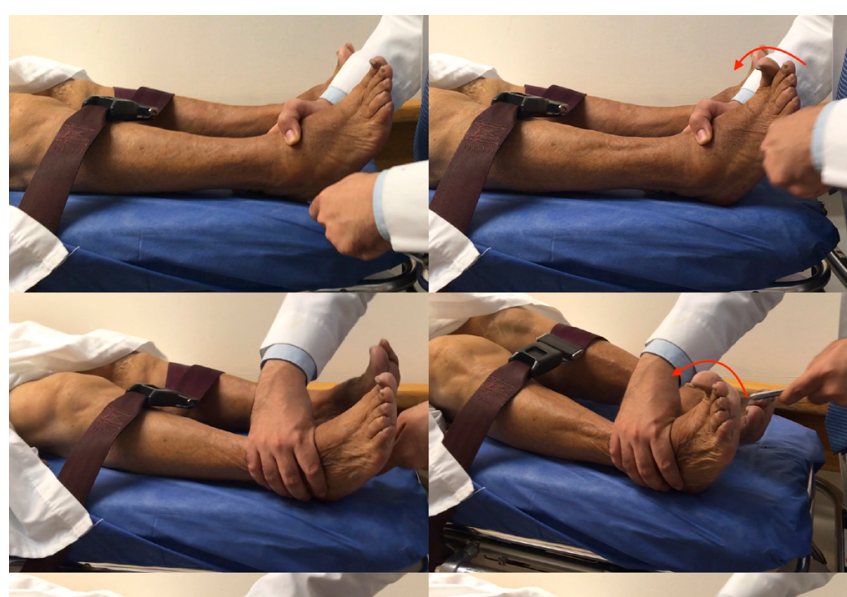

Figure 3. Computed tomography scan. Axial projection showing a hypodensity in the left hemisphere, compromising the complete left middle cerebral artery territory, which appears hyperdense (yellow arrows).

it is paramount to interpret it in the patient's context and not in isolation.

\section{SUPPLEMENTARY FILES}

The following material is available online for this letter:

Supplementary video. The Austregésilo-Esposel Sign. Upon stimulation of the anterior aspect of the thigh, we observe an extensor plantar reflex (https://www.arquivosdeneuropsiquiatria.org/wp-content/uploads/2021/09/ANP-2021.0310-video. mov).

\section{REFERENCES}

1. Novis LE, Maranhão Filho PA, Pires MEP, Spitz M, Teive HAG. Professor Faustino Esposel: neurology, football and spiritualism. Arq Neuropsiquiatr. 2021;79(9):848-50. https://doi.org/10.1590/0004282X-ANP-2021-0013

2. Austregesilo A, Esposel F. Le phénomene de Babinski, provoqué par l'excitation de la cuisse. L'Encéphale. 1912;7:429-36.

3. Hart RG, Catanese L, Perera KS, Ntaios G, Connolly SJ. Embolic stroke of undetermined source: a systematic review and clinical update. Stroke. 2017 Apr;48(4):867-72. https://doi.org/10.1161/ STROKEAHA.116.016414
4. Kakitani FT, Collares D, Kurozawa AY, de Lima PMG, Teive HAG. How many Babinski's signs are there? Arq Neuropsiquiatr. 2010 Aug;68(4):662-5. https://doi.org/10.1590/S0004282X2010000400037

5. Araújo R, Firmino-Machado J, Correia P, Leitao-Marques M, Carvalho J, Silva M, et al. The plantar reflex: a study of observer agreement, sensitivity, and observer bias. Neurol Clin Pract. 2015 Aug 6;5(4):30916. https://doi.org/10.1212/CPJ.0000000000000155 